\title{
Association between vitamin $D$ and cardioprotection in adult patients
}

(D) Gabriel Cavalcante Ferraz ${ }^{1}$

(iD) Raul Ribeiro de Andrade 1

(D) Fernando Minervo Pimentel Reis ${ }^{2}$

(D) Olavo Barbosa de Oliveira Neto ${ }^{3}$

(iDClisivaldo Oliveira de Omena ${ }^{4}$

(iD) Mario Jorge Jucá ${ }^{5}$

DCélio Fernando de Sousa-Rodrigues ${ }^{5}$

(iD) Fabiano Timbó Barbosa ${ }^{5}$

1. Acadêmico de Medicina do Centro Universitário CESMAC, Maceió, $A L$, Brasil. 2. Farmacêutico-Bioquímico da Unidade de Emergência do Agreste Dr Daniel Houly, Maceió, AL, Brasil. 3. Odontólogo da Universidade Federal de Alagoas, Maceió, AL, Brasil.

4. Profissional de Educação Física, Maceió, AL, Brasil. 5. Médico e Professor do Centro Universitário CESMAC, Maceió, AL, Brasil.

http://dx.doi.org/10.1590/1806-9282.66.10.1444

\section{SUMMARY}

OBJECTIVE: To conduct a review of articles which have evaluated the relationship between vitamin D and cardioprotection in adult.

METHODS: A literature search was performed in the Pubmed and Scielo databases. The results were extracted from primary and secondary sources and will be presented in the form of a bibliographic review.

RESULTS: Twenty-three articles were identified from the electronic search that reported on physiological mechanisms relating the vitamin D axis and the cardiovascular system through receptors. Of the ten studies that evaluated the therapeutic effect of vitamin D in cardiovascular diseases, none reported significant results.

CONCLUSION: The articles assessed in this review did not demonstrate a cardioprotective effect of vitamin D, despite the epidemiological correlation of vitamin D deficiency with a higher prevalence of cardiovascular diseases.

KEYWORDS: Vitamin D; Cardiovascular disease; Therapeutics; Prognosis.

\section{INTRODUCTION}

Vitamin D is a hormone which along with parathyroid hormone (PTH), is essential for the regulation of calcium and bone metabolism'. In addition, there are studies indicating that it is related to the pathogenesis of several diseases ${ }^{1}$ (Table 1 ). In recent times, preliminary epidemiological findings from experimental studies have reported about the association of hypovitaminosis D with non-skeletal diseases. According to the recommendations of the Brazilian Society of Endocrinology and Metabology (SBEM) serum concentrations of vitamin D below $20 \mathrm{ng} / \mathrm{mL}(50 \mathrm{nmol} / \mathrm{L})$ are classified as deficiency, between 20 and $29 \mathrm{ng} / \mathrm{mL}$ (50 and $74 \mathrm{nmol} / \mathrm{L}$ ) as insufficiency and between 30 and $100 \mathrm{ng} / \mathrm{mL}$ (75 and $250 \mathrm{nmol} / \mathrm{L}$ ) as normal ${ }^{2}$. 
Currently, the measurement of 25(OH)D is not recommended for the general population ${ }^{2}$. However, it is recommended for the diagnosis of disability in individuals belonging to populations at risk or those in whom the clinical situation correlates with vitamin $\mathrm{D}^{2}$. According to SBEM, candidates for 25(OH)D measurement would be the following groups: patients with rickets or osteomalacia, osteoporosis, elderly patients with a history of falls and fractures, obese people, pregnant women and infants, patients with malabsorption syndromes (cystic fibrosis, inflammatory bowel disease, Crohn's disease, bariatric surgery), renal or hepatic insufficiency, hyperparathyroidism, patients taking medications that interfere with vitamin D metabolism (anticonvulsants, glucocorticoids, antifungals, antiretrovirals, cholestyramine, orlistat), and those with granulomatous diseases and lymphomas ${ }^{2}$.

However, studies indicate that subjects above 35 years of age with vitamin D deficiency had a higher risk of death from cardiovascular disease (CVD) than those with normal level ${ }^{3}$. There is evidence that subjects with chronic conditions had lower levels of vitamin D levels than those without chronic conditions ${ }^{3}$. Some epidemiological studies indicated that vitamin D is a better predictor of risk for coronary disease than diastolic blood pressure (AP) in the elderly ${ }^{4}$. Vitamin $\mathrm{D}$ is inversely proportional to $\mathrm{BP}$, if $\mathrm{BP}$ is higher, vit $\mathrm{D}$ is lower and vice-versa ${ }^{4}$.

The objective of this study was to review the cardioprotective action of vitamin $\mathrm{D}$.

\section{METHODS}

Systematic and traditional reviews of the literature, meta-analyses, and major clinical trials about the relationship between vitamin D and cardiovascular diseases were searched in the Pubmed and Scielo databases. The results of information collected from primary and secondary sources, will be presented in the form of a bibliographic review. A search using the terms "Vitamin D" AND "Cardiovascular Diseases" AND "Drug Therapy", and "Vitamin D" AND "Cardiovascular Diseases" AND "Prognosis” was performed.

The inclusion criteria for the articles selected for this review were the presence of the above terms in the title or abstract of the articles; from these, articles published in English or Portuguese with the full text available for selected for the analysis. After analyzing the entire specific bibliography, consolidated findings of the research were grouped by clinical situations; the

TABLE 1

\begin{tabular}{|c|c|c|c|c|}
\hline Study & $\begin{array}{l}\text { Type of } \\
\text { study }\end{array}$ & Total participants & Posology & Conclusion \\
\hline Witte, et al| & ECR & $\begin{array}{l}\text { Group A: Vitamin D3 } \\
\text { Group B:Placebo } \\
\text { Total: } 223 \text { patients }\end{array}$ & $\begin{array}{l}\text { A: Vitamin D3 of } 4000 \mathrm{IU} \text { daily for } \\
\text { one year } \\
\text { B: Calcium-free placebo }\end{array}$ & $\begin{array}{l}\text { There was no improvement in the 6-minute walk } \\
\text { distance, but vitamin D3 had beneficial effects } \\
\text { on the structure and function of the left ventricle } \\
\text { in patients under contemporary medical therapy }\end{array}$ \\
\hline $\begin{array}{l}\text { Gepner D, } \\
\text { et a }\left.\right|^{17}\end{array}$ & ECR & $\begin{array}{l}\text { Group A: Vitamin D3 } \\
\text { Group B:Placebo } \\
\text { Total: } 114 \text { patients }\end{array}$ & $\begin{array}{l}\text { A: Vitamin D3 } 2500 \text { IU daily for four } \\
\text { weeks } \\
\text { B: Placebo }\end{array}$ & $\begin{array}{l}\text { There was no improvement in endothelial func- } \\
\text { tion, arterial stiffness or inflammation }\end{array}$ \\
\hline $\begin{array}{l}\text { Bernini } G \text {, } \\
\text { et al }{ }^{18}\end{array}$ & ECR & Total: 38 patients & $\begin{array}{l}\text { A: Calcitriol } 0.25 \mu \mathrm{g} \text { for one week } \\
\text { B: Angiotensin II receptor antagonist } \\
\text { and a single dose of cholecalciferol at } \\
300,000 \text { IU for eight weeks }\end{array}$ & $\begin{array}{l}\text { Activation of vitamin D receptor does not } \\
\text { influence the systemic activity of the renin-an- } \\
\text { giotensin system }\end{array}$ \\
\hline $\begin{array}{l}\text { Nsengiyum- } \\
\text { va } V \text {, et al }{ }^{\mathbf{1 9}}\end{array}$ & RS & $\begin{array}{l}\text { Total: } 8 \text { articles with } 529 \\
\text { participants }\end{array}$ & $\begin{array}{l}\text { Vitamin D3 in the following posol- } \\
\text { ogies: } \\
\text { 100,000 IU single dose for } 8 \text { weeks } \\
200,000 \text { IU single dose for } 16 \text { weeks } \\
100,000 \text { IU single dose for } 16 \text { weeks } \\
2000 \text { IU daily for } 16 \text { weeks } \\
4000 \text { IU daily for } 12 \text { weeks } \\
2500 \text { IU daily for } 4 \text { months, } 5000 \text { IU } \\
\text { daily for } 12 \text { weeks } \\
\text { Only one study described the use of } \\
\text { paracalcitriol capsule in the dosage } \\
\text { of } 2 \mu g\end{array}$ & $\begin{array}{l}\text { More clinical trials are necessary to confirm or } \\
\text { reject the benefit of vitamin D3 in endothelial } \\
\text { dysfunction }\end{array}$ \\
\hline $\begin{array}{l}\text { Whitham, } \\
\text { et al }{ }^{23}\end{array}$ & ECR & $\begin{array}{l}\text { Group A: Patients } \\
\text { using } 3 \text { antihypertensive } \\
\text { agents submitted to } \\
\text { vitamin D3 therapy } \\
\text { Group B: Placebo } \\
\text { Total: } 68 \text { participants }\end{array}$ & $\begin{array}{l}\text { A: Vitamin D3 at 100,000 IU every } \\
\text { two months } \\
\text { B: Placebo }\end{array}$ & $\begin{array}{l}\text { No reduction in blood pressure or left ventricular } \\
\text { mass in patients with resistant hypertension }\end{array}$ \\
\hline
\end{tabular}


findings were then homogenized for presentation of the results and to define the conclusions.

\section{Vitamin D metabolism}

The endocrine system of vitamin D is formed by secosteroid molecules derived from 7-hydrocholesterol (7-DHC), its carrier, and receptor proteins ${ }^{5}$. This metabolic axis plays a fundamental role in the regulation of osteomineral physiology, modulation of autoimmunity, synthesis of inflammatory interleukins, blood pressure control, and participates in the process of multiplication and cell differentiation ${ }^{5}$. Synthesis of the active form of vitamin $\mathrm{D}(1 \alpha, 25$-dihydroxyvitamin D or calcitriol), starts in the epidermis by a photolytic reaction mediated by $\mathrm{B} 5$ ultraviolet rays. The precursor of calcitriol reaches the liver through the circulation, where, after conversion of enzymes of the P450 family it becomes 25-hydroxyvitamin D3 or calcidiol ${ }^{6}$.

Calcidiol is the most stable metabolite of vitamin $\mathrm{D}^{6}$. Calcidiol is converted to calcitriol by the epithelial cells of the renal proximal tubules ${ }^{6}$. Its synthesis is stimulated by PTH and is inhibited by the fibroblast growth factor 23 (FGF23) produced in osteocytes ${ }^{7}$. A fall in 25(OH)D3 stimulates PTH production ${ }^{7}$. Vitamin $\mathrm{D}$ is also closely related to factors such as age, obesity, smoking, and a sedentary lifestyle ${ }^{8}$. Besides affecting vitamin $\mathrm{D}$, these are risk factors for cardiovascular disease, which raises the possibility that variations in vitamin $D$ levels are a consequence, not the cause of disease or disease precursor states ${ }^{8}$.

The endocrine system of each individual varies according to some external factors, which might be another cause of discrepancy in the data analysis of large populations ${ }^{8}$. Vitamin D levels are impacted by seasonal variation that influences the amount exposure to sunlight, and color of the skin in which melanin influences the photolytic reaction ${ }^{9}$. Hence, the level of vitamin D is lower in people with dark skin?

\section{Effect on heart activity}

Vitamin D receptor (VDR) exists in several systems ${ }^{10}$. Its spectrum of action is very broad, and studies with microarray show more than 900 potential target genes, corresponding to about $3 \%$ of the human genome ${ }^{10}$. Some of the organs and systems it acts on include: brain, parathyroid gland, lung, heart, bones, lymphatic system, arterial system, liver, pancreas, etc ${ }^{11}$. In the cardiovascular system, vitamin D suppresses the renin-angiotensin-aldosterone (SARS) system, thus controlling the increase in blood pressure ${ }^{11}$.
In 2002 Li et al. performed an in vivo study of expression of the renin gene in mice by suppressing the VDR, and evaluated the blood pressure (BP) and angiotensin II activity ${ }^{11}$. The analysis revealed significantly higher diastolic BP and systolic BP (>20 mmHg) in mice with suppressed VDR ${ }^{12}$.

The deletion of the VDR can affect the relaxation of blood vessels and increase the hypertensive effects of Angiotensin 2 (AngII) infusion ${ }^{13}$. VDR is present in the myocardium and cells of the coronary arteries, which supports a possible pathophysiological mechanism for the association between hypovitaminosis $\mathrm{D}$ and cardiovascular diseases ${ }^{14}$. Vitamin D promotes the proliferation of cardiomio tubules and inhibits the cardiomyoblasts to terminate the cell cycle without inducing apoptosis ${ }^{15}$. VDR also facilitates rapid non-genomic responses by inducing voltage-dependent calcium channels, leading to an increase in the cellular calcium inflow and activation of other messengers, such as cyclic AMP, protein kinase A, and phospholipase $\mathrm{C}^{15}$. Cardiovascular reflexes of the dynamic kidney bone influence the renal metabolism of phosphate and vitamin $\mathrm{D}^{14}$. The growth factor for fibroblasts, a secretory protein expressed in osteoblasts and osteocytes is associated with vascular dysfunction, ventricular hypertrophy, and incident CVD ${ }^{10}$.

\section{What the evidence says}

Vitamin D can be found in the form of ergocalciferol or vitamin D2, and cholecalciferol or vitamin D $3^{2}$. Vitamin D2 can be obtained from yeasts and plants, and is produced for commercial use by irradiation of ergosterol present in mushrooms ${ }^{2}$. In Brasil, the most commonly available form of vitamin $\mathrm{D}$ for treatment and supplementation is cholecalciferol, and this is the metabolite that has proven to be most effective ${ }^{2}$. As a rule of thumb, it can be predicted that for every 100 IU supplemented, an increase of 0.7 to $1.0 \mathrm{ng} / \mathrm{mL}$ in calcidiol concentration is expected ${ }^{2}$ (Table 2).

A randomized clinical trial conducted in the United Kingdom by K. Witte et $\mathrm{al}^{16}$ in 2016, included a total of 223 patients. Two groups were analyzed: placebo group and vitamin D group. Vitamin D3 was administered at a dose of 4,000 IU daily for one year compared to placebo, without calcium. The authors concluded that daily administration of 4,000 IU of vitamin D3 for one year does not improve the 6-minute walking distance, but has beneficial effects on the left ventricular structure and function in patients under contemporary medical therapy. 


\section{TABLE 2}

\begin{tabular}{l|l|l} 
Age ranges & $\begin{array}{l}\text { General popula- } \\
\text { tion (IU) }\end{array}$ & $\begin{array}{l}\text { At Risk popu- } \\
\text { lation }(\text { IU) }\end{array}$ \\
\hline $0-12$ months & 400 & $400-1.000$ \\
\hline $1-8$ years & 400 & $600-1.000$ \\
\hline $9-18$ years & 600 & $600-1.000$ \\
\hline $19-70$ years & 600 & $1.500-2.000$ \\
\hline$>70$ years & 800 & $1.500-2.000$ \\
\hline Pregnant women $14-18$ years & 600 & $600-1000$ \\
\hline Pregnant women $>18$ years & 600 & $1.500-2.000$ \\
\hline Infants $14-18$ years & 600 & $600-1.000$ \\
\hline Infants $>18$ years & 600 & $1.500-2.000$ \\
\hline
\end{tabular}

IU = International Units

FIGURE 1. ROLE OF VITAMIN D IN THE PATHOPHYSIOLOGY OF THE HEART DISEASES

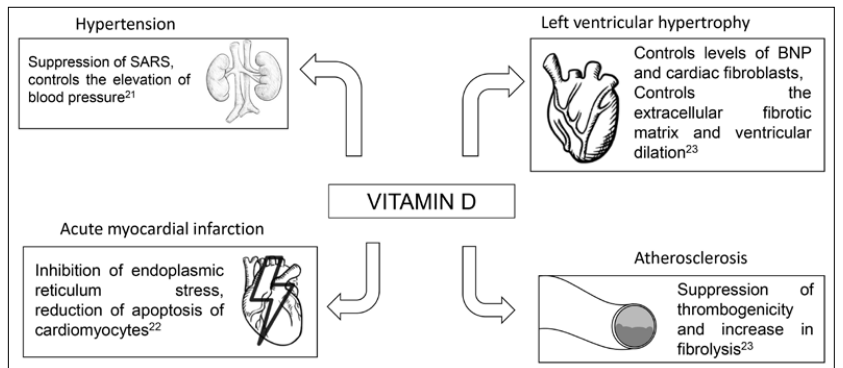

SRAA: Renin-angiotensin-aldosterone system; BNP: Atrial natriuretic peptide.

A randomized clinical trial conducted in the United States by Gepner D et al. ${ }^{17}$ in 2012, included a total of 114 participants. Two groups were analyzed: one group received vitamin D3 and the other group received placebo. In the first group, vitamin D3 was administered at a dose of 2,500 IU daily for four weeks. The authors concluded that vitamin D3 supplementation did not improve the endothelial function, arterial stiffness, or inflammation.

A randomized clinical trial conducted in Italy by Bernini G, et al. ${ }^{18}$ in 2014 included a total of 38 participants. Two groups were analyzed. One group received calcitriol at a dose of $0.25 \mu \mathrm{g}$ for one week, while the other group received angiotensin II receptor antagonist therapy and a only one dose of cholecalciferol at a dose of 300,000 IU for eight weeks. The authors concluded that VDR activation does not influence the systemic activity of the renin-angiotensin system.

A systematic review by Nsengiyumya et al. ${ }^{19}$, published in 2015, analyzed eight studies with a combined sample size of 529 participants. In these studies vitamin D3 was administered in different dosages: 100,000 IU only one dose for 8 weeks, 200,000 IU only onde dose for 16 weeks, 100,000 IU only one dose for 16 weeks, 2000 IU daily for 16 weeks, 4,000
IU daily for 12 weeks, 2,500 IU daily for 4 months, and 5,000 IU daily for 12 weeks. They concluded that more clinical trials are necessary to confirm or reject the benefit of vitamin D3 in endothelial dysfunction.

A randomized clinical trial conducted by Whitham et al. ${ }^{23}$ in the United Kingdom in 2014, included a total of 68 participants. Patients with BP more than 140/90 $\mathrm{mm} \mathrm{Hg}$ and taking three antihypertensive agents were divided into two groups: one group received vitamin D3 and the other received placebo therapy. Subjects in the first group were administered vitamin D3 at a dose of 100,000 IU every two months. They concluded that oral vitamin D3 did not reduce the BP or left ventricular mass in patients with malignet hypertension.

\section{Concluding remarks}

The cardiovascular and renal systems are known to be closely related. The progression of a cardiovascular pathological state involves SARS dysfunction and systemic inflammation that can lead to fluid regulation disorders, which in turn can lead to endothelial dysfunction and myocardial fibrosis. The risk factor in this cycle is a sedentary lifestyle and inadequate nutrition. In addition, the influence of VDR activation on the systemic level of SARS is not well established. It is possible that the supposed causality between vitamin $\mathrm{D}$ and CVD is an indicator of active disease. Hypovitaminosis D would actually be a consequence and not a cause of cardiovascular disease. In addition, chronic diseases can lead to reduced exposure to the sun, sedentary lifestyle, poor dietary intake, poor nutritional status, and thus lower vitamin $\mathrm{D}$ levels.

Clinical trials in this area show conflicting results and authors differ on the therapeutic window for vitamin D supplementation, age, ethnicity, and region. It is not clear if vitamin D has an effect in cases with already established disease.

\section{CONCLUSION}

The articles used in this review did not demonstrate a cardioprotective effect, despite the association of vitamin D deficiency and higher prevalence of cardiovascular diseases in epidemiological studies.

\section{Author's Contribution}

Conception of the idea Gabriel Cavalcante Ferraz; Data collect Gabriel Cavalcante Ferraz, Raul Ribeiro de Andrade; Data analysis and interpretation Gabriel 
Cavalcante Ferraz, Fernando Minervo Pimentel Reis, Olavo Barbosa de Oliveira Neto; Manuscript writing Gabriel Cavalcante Ferraz, Clisivaldo Oliveira de Omena; Relevant critical review of intelectual contente
- Gabriel Cavalcante Ferraz, Mário Jorge Jucá, Célio Fernando de Sousa-Rodrigues; Final approval of the version to be published - Gabriel Cavalcante Ferraz, Fabiano Timbó Barbosa.

PALAVRAS-CHAVE: Vitamina D; Doença cardiovascular; Terapias; Prognóstico

\section{REFERENCES}

1. Lichtenstein A, Ferreira-Júnior M, Sales MM, Aguiar FB, Fonseca FAM, Sumita NM, et al. Vitamina D: ações extraósseas e uso racional. Rev Assoc Med Bras. 2013;59(5):495-506

2. Maeda S, Borba V, Camargo M, Silva D, Borges J, Bandeira F, et al. Recomendações da Sociedade Brasileira de Endocrinologia e Metabologia (SBEM) para o diagnóstico e tratamento da hipovitaminose D. Arq Bras Endocrinol Metab vol.58 no.5 São Paulo 2014.

3. Liu L, Chen M, Hankins R, Nùñez E, Watson A, Weinstock J, et al. Serum 25-hydroxyvitamin $D$ concentration and mortality from heart failure and cardiovascular disease, and premature mortality from all-cause in United States adults. Am J Cardiol. 2012 Sep 15;110(6):834-9.

4. Scragg R, Sowers M, Bell C. Serum 25-hydroxyvitamin D, ethnicity, and blood pressure in the Third National Health and Nutrition Examination Survey. Am J Hypertens. 2007 Jul;20(7):713-9

5. Dobnig H, Pilz S, Scharnagl H, Renner W, Seelhorst U, Wellnitz B, et al. Independent association of low serum 25-hydroxyvitamin d and 1,25-dihydroxyvitamin d levels with all-cause and cardiovascular mortality. Arch Intern Med. 2008 Jun 23;168(12):1340-9

6. Kimball S, Fuleihan Gel-H, Vieth R. Vitamin D: a growing perspective. Crit Rev Clin Lab Sci. 2008;45(4):339-414.

7. Martin H, Fiona B, Katie E, David L, David S, Philip L, et al. Extra-renal 25-hydroxyvitamin D3-1 $\alpha$-hydroxylase in human health and disease. I Steroid Biochem Mol Biol. 2007;103(3-5):316-21.

8. Beveridge LA, Struthers AD, Khan F, Jorde R, Scragg R, Macdonald HM Effect of Vitamin D Supplementation on Blood Pressure: A Systematic Review and Meta-analysis Incorporating Individual Patient Data. JAMA Intern Med. 2015;175(5):745-54

9. Martins D, Wolf M, Pan D, Zadshir A, Tareen N, Thadhani R, et al. Prevalence of cardiovascular risk factors and the serum levels of 25-hydroxyvitamin D in the United States: data from the Third National Health and Nutrition Examination Survey. Arch Intern Med. 2007;167(11):1159-65.

10. Jorge A, Cordeiro J, Rosa M, Bianchi D. Deficiência da Vitamina D e Doenças Cardiovasculares. Int. j. cardiovasc. sci, 2018; 31(4): 422-432

11. Legarth C, Grimm D, Wehland M, Bauer |, Krüger M. The Impact of Vitamin D in the Treatment of Essential Hypertension. Int. J. Mol. Sci. 2018;19, 455

12. Li Y, Kong J, Wei M, Chen Z, Liu S, Cao L.1,25-Dihydroxyvitamin D3 is a negative endocrine regulator of the renin-angiotensin system. J. Clin. Invest 2002; 110:229-238.
13. Ni W, Watts W, Ng M, Chen S, Glenn J, Gardner G. Elimination of vitamin D receptor in vascular endothelial cells alters vascular function. Hypertension. 2014;64(6):1290-8

14. Witte K, Byrom R, Gierula J, Paton F, Jamil A, Lowry E, et al. Effects of Vitamin D on Cardiac Function in Patients With Chronic HF.J Am Coll Cardiol. 2016 Jun 7;67(22):2593-603

15. McDermott M, Liu K, Ferrucci L, Tian L, Guralnik |, Kopp P, et al.Vitamin D status, functional decline, and mortality in peripheral artery disease. Vasc Med. 2014 Feb;19(1):18-26

16. Elamin MB, Abu Elnour NO, Elamin KB, Fatourechi MM, Alkatib AA, Almandoz IP, et al.Vitamin D and cardiovascular outcomes: a systematic review and meta-analysis.) Clin Endocrinol Metab. 2011;96(7):1931-42

17. Gepner D, Ramamurthy R, Krueger C, Korcarz E, Binkley N, Stein I. A prospective randomized controlled trial of the effects of vitamin $D$ supplementation on cardiovascular disease risk. PLoS One. 2012;7(5):e36617

18. Bernini G, Carrara D, Bacca A, Carli V, Virdis A, Rugani I, et al. Effect of acute and chronic vitamin $D$ administration on systemic renin angiotensin system in essential hypertensives and controls. J Endocrinol Invest. 2013 Apr;36(4):216-20

19. Nsengiyumva V, Fernando M, Moxon J, Krishna S, Pinchbeck J, Omer S, et al. The association of circulating 25-hydroxyvitamin D concentration with peripheral arterial disease: A meta-analysis of observational studies. Atherosclerosis. 2015; 243(2):645-51.

20. Muscogiuri G, Annweiler C, Duval G, Karras S, Tirabassi G, Salvio G, et al. Vitamin $D$ and cardiovascular disease: From atherosclerosis to myocardial infarction and stroke. Int J Cardiol, 2017; 230: 577-584.

21. Wu-Wong R, Nakane M, Ma |, Ruan X, Kroeger E, et al. Effects of Vitamin $D$ analogs on gene expression profiling in human coronary artery smooth muscle cells. Atherosclerosis. 2006;186(1):20-8.

22. Weishaar E, Simpson U. Involvement of vitamin D3 with cardiovascular function. II. Direct and indirect effects. Am | Physiol. 1987:253(6 Pt 1):E675-83.

23. Witham MD, Ireland S, Houston JG, Gandy S), Waugh S, Macdonald M, et al. Vitamin D therapy to reduce blood pressure and left ventricular hypertrophy in resistant hypertension: randomized, controlled trial. Hypertension. 2014 Apr; 63(4):706-12 